\title{
Learners Interaction In Learning With Audio On Demand
}

\author{
Zainul Abidina, Arafah Husna ${ }^{\text {b }}$ \\ Malang State University, Malang, Indonesia \\ Corresponding e-mai: azainul.abidin.fip@um.ac.id, barafah.husna.fip@um.ac.id
}

\begin{abstract}
The study presents a case study to evaluate the use of Audio Technology WhatsApp to support asynchronous audio discussions. The study discusses the possibility of learning strategies and pedagogic thinking. Technology is implemented in modules for learning activities. The focus of the study is the possibility of Audio Technology to create learning objects and facilitate peer-to-peer learning. Audio communication is a richer medium of meaning because it can analyze, tone, emphasis and increase personalization in relation to the prevention of misinterpretations. Feedback from lecturers and students on the affordances and voice communication constraints presented
\end{abstract}

Keywords: Audio on Demand, peer-to-peer learning

\section{INTRODUCTION}

An Audio Post Audio Technology (T3A) is an audio asynchronous discussion forum. The study provides a strategic value to discuss the use of T3A generated by WhatsApp, a company that provides software that enables collaborative learning for education. WhatsApp with T3A allows users to record and send audio, audio and text, and text messages only without the need for additional software or knowledge of complex audio editing tools.

Students majoring in Education Technology (TEP) State University of Malang (UM) using T3A for social activity needs. So little research into the use of T3AS in learning and teaching. Therefore, this study has a case study orientation that involves the use of T3A WhatsApp in discussion-based learning for the needs of research writing, articles and final assignments in the eyes of the ulema. T3A WhatsApp is a live audio technology that can be used as an alternative practice report based on or restricted personal account (Weimer 2006). Many of these accounts have been criticized for not being open and prone to failing to reference educational literature and building prior knowledge (Weimer 2006, 62).

Learning is a communication activity. Sync communication involves realtime communication and requires all participants to be online at the same time (Salmon 2004). Research studies are related to Asynchronous in the form of audio discussions where comments are recorded that can be listened to, and and can respond later. Audio has been used in education for many years through radio, cassettes and CDs. Recently the ability to record and share audio has been made available using streaming audio files online. These files are often called Audio Devices and can be downloaded. Historically, permanent media such as audio cassettes and Audio Devices felt lack of interactivity (Junor 1992). T3A WA provides a means to overcome this by using various gadgets to interact with each other through asynchronous audio discussions. More and more literature on using Audio Devices to learn as discussed below, but much less on the use of T3A WA.

Educators have adopted two pedagogical models when incorporating Audio Devices into their programs: information transmission models and social constructivist models. The most commonly used is the information transmission model; Eg, Audio Course lecture notes, seminar discussions, step-by-step video (tutorials) problem solving, inspection preparation information, additional materials and induction information. The survey found positive students about the Audio Device (Maag 2006; Chan, Lee, and McLoughlin 2006; Evans 2008; Malan 2007; Tynan and Colbran 2006). Common themes in students 'perception of Audio Devices' advantages are as follows

1. Repetition Students can listen / watch Audio Devices many times (Belanger 2005; Edirisingha, Rizzi, and Nie 2007; Maag 2006; Tynan and Colbran 2006). 
This can also lead to their increased time spent on learning and promoting the use of other resources ( Maag 2006).

2. Revisions. Audio tools can help with the preparation of the assessment (Aldrich, Bell, and Batzel 2006; Evans 2008; Tynan and Colbran 2006).

3. Flexibility. Audio devices can potentially be accessed anytime, anywhere on a mobile device. It is considered socially acceptable to listen to your MP3s (Clark and Walsh 2004). This can lead to informal learning where students feel that learning is 'accidental' without the need for deep concentration (Edirisingha, Rizzi, and Nie 2007). However, this may be more the case for the Audio Device radio magazine, aimed at sending general points and stimulating interest, rather than complex subject matter (Lee and Chan 2007).

4. Convenience. They can listen at convenient times for students and allow students to catch up on missed lectures (Aldrich, Bell, and Batzel 2006; Maag 2006).

5. Learner can review the material at their own pace and selectively replay the part (Aldrich, Bell, and Batzel 2006; Tynan and Colbran 2006) Extra explanation Audio Devices can offer clarification, facilitate improved understanding of important or difficult concepts (Aldrich, Bell, and Batzel 2006, Belanger 2005).

6. Motivation They can be motivated by adding variety (Edirisingha 2006; Schlosser and Burmeister 2006), although this may derive novel effects (Malan 2007).

However, there has been little empirical evidence to explain the Audio Device following the communication model that is an effective learning tool. Malan (2007) found that learners lack access to Audio Devices available or in their possession. Audio devices have not been used for lectures and build solutions to problems in the course. Accessed more often by students having lower learning achievement than high achieving students, but analysis did not show a correlation between Audio Device access and grade improvement or improved learning outcomes (Berger 2007).

The development of T3A allows learning that has characteristics not to meet. Benefits have been claimed for certain types of learners; For example, remote students, where there is little or no face-to-face contact with tutors and between students. Lee and Chan (2007) succeeded in using Audio Device to overcome the distance learners' anxiety. Hearing the voice of the teacher can help the student to develop a positive social bond with him, and audio cues such as intonation and emphasis can guide students in which to channel their studies (Lee and Chan 2007). Audio gestures can also help prevent misinterpretation (Schlosser and Burmeister 2006), and a regular Audio Device can help distance students with time and organizational management,

T3A technology has many advantages. Audio can benefit from hearing authentic sounds, such as language students (Edirisingha, Rizzi, and Nie 2007; Cho and Carey 2001). Audio devices have been used to support language learners developing listening strategies (O'Bryan and Hegelheimer 2007). Audio tools from the lecture also allow international students who do not learn in their first language to replay lectures and take notes at their own pace (Belanger 2005; Schlosser and Burmeister 2006; Shannon 2006). Audio devices can make learning more accessible to students with specific disabilities such as visual disturbance or dyslexia.

Audio devices have also been used for scaffolding learners, a common example is audio feedback. Kates (1998) finds audio feedback has special benefits for students who often have jobs outside of college hours. Similar to distance learners, they feel more personalized audio and help them feel valued as an individual by the tutor, and the tone of the tutor's voice shows his reaction to the task. McCormack and Taylor (2006) found the Audio Device reduced the time and resources needed to provide audio feedback that returned to the design work. When student presentations are recorded, improved and made available to their peers, peer evaluation can take place (Edirisingha, Rizzi, and Nie 2007; Lee 2006). There are several reports in the literature using audio in social constructivist models. Many MP3 players can be used to record audio as well as play it, allowing students to collect interview data, field notes, group discussions and assignments (Belanger 2005). In one study, students recorded interview data using the iPod, and then presented their data analysis to the class Via Audio Device (Martin 2005). Chan, Lee, and McLoughlin (2006) requested the two years of Information Technology students to produce Audio Devices to help first-year students. Vallance and Shibata (2008) put students in 
groups and asked them to produce interactive activities where they interviewed each other about Topics related to the course, then add pictures, Links and quizzes to Audio Devices. Audio devices are then created as a learning tool. This study shows that students producing Audio Devices for their peers can promote peer-to-peer collaborative learning and individual reflection and cognition, as well as develop transferable skills such as communication skills, teamwork and problem solving. Middleton (2009) suggests that the use of audio in an online environment that has been able to dominate text-based makes them feel more in the human space by enhancing the feeling of social presence; Lack of social presence and isolated feelings is a barrier to online learning (Muilenburg and Berge 2005; Newberry 2001). This study shows that students producing Audio Devices for their peers can promote peer-to-peer collaborative learning and individual reflection and cognition, as well as develop transferable skills such as communication skills, teamwork and problem solving. Middleton (2009) suggests that the use of audio in an online environment that has been able to dominate text-based makes them feel more in the human space by enhancing the feeling of social presence; Lack of social presence and isolated feelings is a barrier to online learning (Muilenburg and Berge 2005; Newberry 2001). This study shows that students producing Audio Devices for their peers can promote peer-to-peer collaborative learning and individual reflection and cognition, as well as develop transferable skills such as communication skills, teamwork and problem solving. Middleton (2009) suggests that the use of audio in an online environment that has been able to dominate text-based makes them feel more in the human space by enhancing the feeling of social presence; Lack of social presence and isolated feelings is a barrier to online learning (Muilenburg and Berge 2005; Newberry 2001). As well as developing transferable skills such as communication skills, teamwork and problem solving. Middleton (2009) suggests that the use of audio in an online environment that has been able to dominate text-based makes them feel more in the human space by enhancing the feeling of social presence; Lack of social presence and isolated feelings is a barrier to online learning (Muilenburg and Berge 2005; Newberry 2001). As well as developing transferable skills such as communication skills, teamwork and problem solving. Middleton (2009) suggests that the use of audio in an online environment that has been able to dominate text-based makes them feel more in the human space by enhancing the feeling of social presence; Lack of social presence and isolated feelings is a barrier to online learning (Muilenburg and Berge 2005; Newberry 2001).

\section{COMMUNICATION SPECIALLY IN LEARNING WEB}

THE

In Learning Development, a blended system uses Web-based and Web-based direct Ansyncronous (ASyncronous) learning technology, with a terminology to describe how and when specific course studies take place.

\subsection{Direct Learning (Syncronous Learning)}

In the direct learning of learning computer courses, the learning and teaching process takes place in the same time (real time) although the teachers and the students are physically located in different places with each other.

\subsection{Indirect (Ansyncronous Learning)}

In indirect learning, learning process and teaching course Computer learning takes place with the delay / delay time delay (different time) and the teacher and students are physically located in different places.

Example:

1. Learn yourself using the internet or.

2. Web presentation or seminar using audio / video.

3. Tutorial recording.

4. Mentoring question and answer.

5. Read e-mail messages.

6. Accessing web-based content

7. Web-based discussion forums

Characteristics of indirect learning (Ansyncronous) is the developer or the teacher must prepare the first learning materials before the learning process takes place. Students are free to decide when to learn the learning materials. 


\subsection{Results of Learning Analysis in T3wa}

Respondent students have the ability to download them and the ability to discuss using T3A WA. Being able to communicate builds social ties and trust in community learning and discussion.

During T3A WA used in learning, learning strategies use principles to select, create and design tasks that learners use to support activities. The lecturers then put the theory into practice and create the task of listening to the material of their choice, either using the existing device or creating their own, and designing a series of activities around it. A T3A is used to support students. Students can use T3A to record listening tasks, or they can upload their Audio Devices have been created or obtained elsewhere. Students must upload a listening task to the virtual T3A teacher room in WA, so they are all in one place to share with their colleagues and teachers. T3A WA is used by lecturers to provide formative feedback. Students are given three days to use T3A WA to supply feedback on at least two of their peer work As a task that students need to evaluate other students' listening tasks, synchronous audio devices will not be appropriate.

\section{CONCLUSION}

T3AS can be used as part of a learning strategy, and to share students courses in TEP UM, with special reference to WhatsApp T3A technology, to enable a deeper understanding of T3AS in the learning technology community.

The educational context of the selected case and explains the case study methodology and how T3A technology can be used in learning in the TEP UM department. The case study results are an evaluation of the effectiveness of learning strategies and learning technologies, and review lecture activities by utilizing T3A.

\section{REFERENCES}

[1] Aldrich, D., B. Bell, and T. Batzel. 2006. Automated podcasting solution expands the boundaries of the classroom. In SIGUCCS '06: Proceedings of the 34th annual ACM SIGUCCS conference on User services, 14. New York: ACM Press.
[2] Belanger, Y. 2005. Duke University iPod first year experience final evaluation repo rt. Http://cit.duke.edu/pdf/reports/ipod_ini tiative_04_05.pdf (accessed November 19 , 2007).

[3] Berger, E. 2007. Podcasting in engineerin g education: A preliminary study of conte $\mathrm{nt}$, student attitudes, and impact. Innovate 4 , no. 1. ht tp://www.innovateonline.info/index.php? view $=$ article $\&$ id $=426$ edn.

[4] Chan, A., MJW Lee, and C. McLoughlin. 2006. Everyone's learning with podcastin g:

[5] Charles Sturt University experience. In T he $23 \mathrm{rd}$ annual conference of the Australa sian

Society for Computers in Learning in Tert iary Education, 111-20. Sydney: Sydney University Press.

[6] Cho, S., and S. Carey. 2001. Increasing K orean oral fluency using an electronic bull etin board and Wimba based voiced chat. The Korea $n$ Language in America 6: 115-28.

[7] Clark, D., and S. Walsh. 2004. iPodlearning. White paper. Brighton, UK: Epi c Group.Edirisingha, P. 2006. The 'double life' of an iPod: A case study of the educational pote ntial

of new technologies. Paper presented at $\mathrm{t}$ he 12th International Conference on Tech nolog

[8] Supported Learning \& Training, Online Education.https:

//lra.le.ac.uk/handle/2381/406? Mode = full $\&$ submit_simple $=$ Show + full + item + record (accessed November 25, 2009).

[9] Edirisingha, P., C. Rizzi, and M. Nie. 200 7. Podcasting to provide teaching and lear ning

support for an undergraduate module on English language and communication. Tu rkish

Online Journal of Distance Education 8, $\mathrm{n}$ o. 3: 87-107.

[10] Evans, C. 2008. The effectiveness of mlearning in the form of podcast revision le ctures higher education. Computers \& Educatio n 50, no. 2: 491-8.

[11] Garrison, D., and T. Anderson. 2003. Elearning in the 21 st century. London: Rou tledge Falmer.

[12] Junor, L. 1992. Teaching by tape: So me benefits, problems, and solutions. D istance Education 13, no. 1: 93-107. 
[13] Kates, R. 1998. Tape recorders and the co mmuter student: Bypassing the red pen. T eaching English in the TwoYear College 25, no. 1: 21-4.

[14] Kolb, D. 1984. Experiential learning: Exp erience as the source of learning and deve lopment. London: Prentice-Hall.

[15] Laurillard, D. 2002. Rethinking universit y teaching: A framework for the effective use

of educational technology. 2nd ed. London: RoutledgeFalmer.

[16] Lave, J., and E. Wenger. 1991. Situate d learning: Legitimate peripheral particip ation. Cambridge: Cambridge University Press.

[17] Lee, MJW 2006. Using blogs and podcast ing to facilitate delivery and self / peer evaluation of oral presentation assessments. Learnin g Technology 8, no. 4: 28-30.

[18] Lee, MJW, and A. Chan. 2007. Reducing the effects of isolation and promoting incl usivity

for distance learners through podcasting. Turkish Online Journal of Distance Educa tion 8 , no. 1: 85-105.

[19] Maag, M. 2006. iPod, uPod? An emergin $\mathrm{g}$ mobile learning tool in nursing educatio $\mathrm{n}$ and students' satisfaction. In The 23rd annual conference of the Australasian Society for Computers in Learning in Tertiary Educat ion,

48392. Sydney: Sydney University Press.

[20] Malan, DJ 2007. Podcasting computer sci ence

E1. In SIGCSE '07: Proceedings of the $38 \mathrm{t}$ h SIGCSE technical symposium on Comp uter science education, 38993. New York: ACM Press.

[21] Marriott, P., and J. Hiscock. 2002. Voice vs. textbased discussion forums: An implementat ion of Wimba Voice Boards. In ELearn conference, 6406. Norfolk, VA: Association for the Advancement of Computing in Education (AACE).

[22] Martin, CE 2005. Special education iPod project. Http://hercules.gcsu.edu/ cmartin / SpecialEd.htm (accessed November 5, 2 010).

[23] McCarty, S. 2005. Spoken Internet to go: Popularization through podcasting. JALT CALL 1, no. 2: 67-74.

[24] McCormack, C., and M.J. Taylor. 2006. Electronic delivery of oral feedback on gr aphic

design projects. In The 23rd annual confe rence of the Australasian Society for Com puters

in Learning in Tertiary Education, 5258. Sydney: Sydney University Press.

[25] McIntosh, S., B. Braul, and T. Chao. 200 3. A case study in asynchronous voice co nferencing

for language instruction. Educational Me dia International 1469-5790 40, no. 1: 6374.

[26] Middleton, A. 2009. Beyond podcasting: Creative approaches to designing educati onal audio. ALT-J 17, no. 2: 143-55.

[27] Muilenberg, L., and Z. Berge. 2005. Stud ent barriers to online learning: A factor an alytic study. Distance Education 26, no. 1: 2948.

[28] Newberry, B. 2001. Raising student socia 1 presence in online classes. In Proceedin gs WebNet 2001 World Conference on the WWW and the Internet, ed. W. Fowler an d J. Hasebrook, 90510. Orlando, FL: Association for the Adv ancement of Computing in Education (AACE).

[29]Nicol, DJ, and D. MacfarlaneDick. 2006. Formative assessment and sel f-regulated learning:

[30] A model and seven principles of good fee dback practice. Studies in Higher Educati on 31 ,

[31]No. 2: 199-218.

[32] Oates, BJ 2006. Researching information systems and computing. London: Sage.

[33] O'Bryan, A., and Hegelheimer, V. 2007. I ntegrating CALL into the classroom: The role of podcasting in an ESL listening strategies course. ReCALL 19, no. 2: 162-80.Pask, G. 1976. Conversation theory: Applications in education and epistemology. Amsterdam: Elsevier.

[34] Ross, KW 2003. Asynchronous voice: A personal account. IEEE MultiMedia 10, n o. 2: 70-4. Salmon, G. 2004. Emoderating: The key to teaching and lear ning online. 2nd ed. London: Routledge Falmer.

[35] Schlosser, CA, and ML Burmeister. 2006. Audio in online courses: Beyond podcasting. http://www.nova.edu / bur meist audio_online.html (accessed August 2, 20 07). 
[36] Shannon, SJ 2006. Why do not students attend lectures and what can be done about it through using iPod nanos? In The 23rd annual con ference of the Australasian Society for Co mputers

in Learning in Tertiary Education, 7536. Sydney: Sydney University Press.

[37] SurveyMonkey.com 2008. SurveyMonk ey.com because knowledge is everythi ng.

Http: // www.surveymonkey.com (accessed Jun e 20, 2008).

[38] Tynan, B., and S. Colbran. 2006. Podcasti ng, student learning and expectations. In The 23 rd annual conference of the Austr alasian Society for Computers in Learnin $\mathrm{g}$ in Tertiary Education, 82532. Sydney: Sydney University Press.
[39] Vallance, M., and Shibata, Y. 2008. Effective implementation of interactive podcasting for the Web 2.0 generation. The JALT CALL Jo urnal 4, no. 1: 60-74.

[40] Vygotsky, LS 1978. Mind in society: The development of higher psychological proc esses. London: Harvard University Press.

[41] Weimer, M. 2006. Enhancing scholarly w ork on teaching and learning: Professiona 1 literature that makes a difference. San Fr ancisco, CA: Jossey-Bass.

[42] Wood, D., J. Bruner, and G. Ross. 1976. The role of tutoring in problem solving. $\mathrm{J}$ ournal

of Child Psychology and Psychiatry 17: 89100. 